\title{
Read the world to write the future: An interview with professors E Wayne Ross and Xosé Manuel Souto, experts in critical social studies
}

\author{
Leer el mundo y escribir el futuro: Entrevista con los profesores $E$ \\ Wayne Ross y Xosé Manuel Souto, expertos en estudios sociales \\ críticos
}

Jordi Castellví Mata

Universidad Internacional de la Rioja

\begin{abstract}
Read the world to write the future: An interview with professors E Wayne Ross and Xosé Manuel Souto, experts in critical social studies.

E Wayne Ross is professor at the University of British Columbia (Canada). He is interested in the influence of social and institutional contexts on teachers' practice as well as the role of curriculum and teaching in building a democratic society in the face of antidemocratic impulses of greed, individualism, and intolerance.

Xosé Manuel Souto is professor at the University of Valencia (Spain), in the department of social and experimental sciences education. He directs the GeaClío educational innovation group that has developed, for the past thirty years, its work in the fields of teacher training, creation of curricular material and educational research.
\end{abstract}

Keywords: Critical literacy; Counter-hate speech; Global citizenship; Critical social studies

\section{Resumen}

E Wayne Ross es profesor de la University of British Columbia (Canadá). Está interesado en la influencia de los contextos sociales e institucionales en la práctica de los docentes, así como en el papel del plan de estudios y la enseñanza en la construcción de una sociedad democrática frente a los impulsos antidemocráticos de la codicia, el individualismo y la intolerancia.

Xosé Manuel Souto es profesor catedrático de la Universitat de València (España), en el departamento de didáctica de las ciencias sociales y experimentales. Destaca su participación en la coordinación y dirección del grupo de innovación educativa Gea-Clío que continúa desarrollando, desde hace treinta años, su labor en los ámbitos de la formación docente, elaboración de material curricular e investigación educativa.

Palabras clave: Literacidad crítica; Contrarrelatos del odio; Ciudadanía global; Estudios sociales críticos 
INTERVIEWER ${ }^{1}$ : We are living hard times. It seems more evident than ever that we are part of a global citizenship: a virus, that supposedly started in China, spread rapidly to the rest of the world thanks to global mobility of people. The economy effect of the epidemic affected the entire world faster than it became a pandemic. However, countries acted on their own, and very little initiatives tried to solve the problem globally, with collaboration of every country.

What do you think should be the role of Global Citizen Education in present times? When we teach it, on what should we focus? What should be its main aims?

ROSS: There is no doubt that the rapid spread of coronavirus, the resultant pandemic and its impact on the global economy illustrate how globally interconnected humanity and economies are in the $21^{\text {st }}$ Century. That said, I think there are some important issues that need to be teased out when we try to make sense of what is happening and how we have or can respond to this crisis, as well as other global crises, such as climate change, economic inequalities, threats to human rights, etc.

First, the obvious global interconnectedness illustrated by the pandemic cannot be equated with any sort of global 'citizenship' at least not in any formal sense. Early in the pandemic, "we are all in the same boat" was a popular phrase to describe the how the virus affects everyone. But this was/is not true. And as the differential effects of the pandemic became clear this sentiment was altered to "we are in the same storm, but not in the same boat. One person's ship can be shipwrecked, and another's might not be". These differing effects can be seen in public health responses and guidelines, access to health care, employment, and how differing circumstances effects teachers work and students' access to education, particularly virtual learning. The problematic prior assumptions of the sentiment "we are all in this together" have long been a problem in education because this simple phrase that asserts equity and equality in social relations when it is actually an ideal or aspiration, but not a reality. As I have pointed out elsewhere ${ }^{2}$, teaching about and for democracy in schools is typically built on the lie that in social, political, and economic institutions in so-called democratic countries treat everyone equally.

Secondly, but following from the same logic, when we ask, "what should be the role of Global Citizenship Education (GCE) in present times?" we need to deconstruct what we are talking about. GCE has become a wildly popular concept

\footnotetext{
${ }^{1}$ This interview took place between August and October 2020.

${ }^{2}$ See for example: Ross, E. W. (2017). Rethinking social studies: Critical pedagogy in pursuit of dangerous citizenship. Information Age Publishing.
} 
with educators, researchers, as well as education administrators in schools and universities that describes the globalization or internationalization of education. GCE claims or perhaps aims to be a response to globalization and the values of citizenship. But when GCE is invoked as a framework what assumptions are being made about citizenship and globalization? Indeed, upon closer analysis GCE can be seen as harbouring competing and contradictory discourses critical democracy and neoliberalism.

While I believe GCE has the possibility to be a counterforce to individualism and neoliberal capitalism. GCE is more typically a container for individualism and neoliberal capitalism that compromises or blunts any potential resistance democratic discourses within GCE offers. GCE in its most popular (if superficial) conception is about empowering learners to understand that issues such as human rights, inequality, poverty, peace and sustainability are global/local issues, and that people can take actions in their everyday lives to create more tolerant, peaceful, and sustainable societies. This idea of GCE has the potential to challenge the idea of individuals as primarily consumers, homo economicus, using rational assessments to maximize utility as a consumer and profit producer. In GCE there is the implication that people have agency, that there are universal human values that are pro-human that can be activated to improve the world. I don't believe GCE is consistently conceptualized as anti-individualist or anti-capitalist. Indeed, the language of security and capitalist economic development runs deeply within most examples and conceptualizations of GCE. In a recent article, Pais and Costa $^{3}$ present an ideology critique of GCE makes the same point. They argue that critical democratic discourse within GCE does not offer any resistance to neoliberal restructuring of education. A fact that most likely explains it rapid and widespread adoption as an important theoretic framework in educational reform. While GCE highlights the importance of ethical values, social responsibility and active citizenry (e.g., critical democracy), it also privileges a market-rationale, focused on self-investment and enhanced profits (e.g., neoliberalism). Pais and Costa argue these discourses are not separated, but exist side by side within GCE, causing a confusing effect.

So, to get back to your questions about GCE, the first thing that we should do is clarify what we mean by GCE and whether that is the framework we want to be working within as educators and researchers. When asked if neoliberalism and education are compatible, my answer is: no, they are not. At root this

\footnotetext{
${ }^{3}$ See: Pais, A., \& Costa, M. (2020). An ideology critique of global citizenship education. Critical Studies in Education, 62(1), 1-6. https://doi.org/10.1080/17508487.2017.1318772
} 
incompatibility stems from the antipathetic relationship between capitalism and democracy - and by democracy, I mean a radical democracy, the rule of the people, not plutocracy which is the more accurate term for neoliberal democracy. I am sympathetic to the pragmatic aims of your questions about what our aims should be and should be taught. I do not think there can be a universal answer, because we are not all in the boat. But it is important to remember that schools are sites of an unresolved ambiguity, the source of both alienation and-at least potentiallyemancipation. We might consider a question such as this: Are public schools the source of hidden riches and starting points for the transformation of society or are they impoverished zones to which the construction of real education can only be opposed? The initial challenge for anyone interested in the creation of schools and education that serves the public interest is to negate what has become the prevailing, neoliberal, image of a successful school and what has come to constitute good learning and teaching under the reign of neoliberalism.

SOUTO: Empezaré comentando la afirmación de Wayne Ross: "I am sympathetic to the pragmatic aims of your questions about what our aims should be and should be taught. I do not think there can be a universal answer, because we are not all in the boat..."

Creo que hay que diferenciar dos aspectos. Es cierto que no toda la humanidad, sus individuos, gozan de las mismas condiciones de vida, pero sí que están en la misma aventura vital. Los más poderosos no pueden sobrevivir sin los más pobres. Y en el caso de la pandemia se ha hecho evidente que la fe ciega en el progreso, en el desarrollo de la tecnología, se ha venido abajo. Y personas poderosas también han sufrido el impacto del virus, de forma directa o indirecta. En un manifiesto ${ }^{4}$ que acabamos de publicar, y que está recogiendo múltiples adhesiones, explicamos que el virus ha afectado a la concepción de la humanidad como un ente global y, al mismo tiempo específico: "una pandemia afecta no solo a su modelo de convivencia social, sino también a su desarrollo biológico. Ambas dimensiones están conectadas en el plano personal y colectivo". Las consecuencias biológicas, psicológicas y culturales derivadas de la pandemia serán evaluadas con la perspectiva histórica, pero parece evidente que será necesario utilizar las diferentes escalas territoriales y cronológicas para valorar su impacto en cada uno de los individuos de la especie humana.

\footnotetext{
${ }^{4}$ Manifesto 'As lições da pandemia - las enseñanzas de la pandemia - uma proposta de atuação'. Available at: http://www.socialsuv.org/manifiesto
} 
No se puede hablar de ciudadanía global en abstracto. Habrá que analizar qué tipo de interrelación ecológica estamos dispuestos a asumir. Si seguimos como depredadores de recursos abióticos, bióticos y culturales la evolución del ser humano estará determinada por crisis regulares, de mayor o menor virulencia y que, sin duda, afectarán a poblaciones más y menos vulnerables. Pero el modelo de vida se verá afectado. Esto es lo que tenemos que explicar en las clases del sistema escolar. Y explicar que bajo los grandes conceptos (ciudadanía, democracia, participación) hay deseos, expectativas personales, que interpretan los hechos sociales con el sentido práctico que han aprendido para justificar su posición en el mundo. Por eso me parece pertinente la propuesta de Educación Ciudadana Global entendida como tratar de empoderar a los estudiantes para que comprendan que temas como los derechos humanos, la desigualdad, la pobreza, la paz y la sostenibilidad son problemas globales / locales y que las personas pueden tomar acciones en su vida diaria para crear sociedades más tolerantes, pacíficas y sostenibles.

Pero a mi modo de ver, ello se tiene que hacer impugnando las representaciones sociales del saber escolar, que simplemente es un compendio de hechos asentados en la cultura capitalista occidental y una forma de razonar propia del liberalismo individualista. En concreto, hay aspectos de la pandemia que se analizan en las clases de Biología (como la diferencia entre $\mathrm{ADN}$ y $\mathrm{ARN}$ ) que muchas personas desconocen, como también no se conoce la respuesta del virus ante una determinada composición genética de las personas infectadas. Ello debe ser trabajado no solo desde el ámbito científico experimental o físico, sino también desde las ciencias sociales, para mostrar cómo las investigaciones básicas o las aplicadas tienen sus horizontes y sus tiempos. No es lo mismo el tiempo de la investigación que el de la publicidad, no es lo mismo una escala cronológica histórica que otra determinada por los intereses de las audiencias de los medios de comunicación. Y aquí tenemos una enorme responsabilidad las personas que trabajamos con problemas sociales y en el ámbito educativo escolar.

Es preciso abordar estas cuestiones de problemas esenciales de la humanidad con una perspectiva de transformación de un dilema social en una cuestión escolar; es decir, como la preocupación por una vacuna o un tratamiento contra el virus se puede trasformar en un problema escolar, en el que el alumnado pueda participar en el debate sobre su comprensión y, de este modo, transmitirlo a otras personas. Y eso no se suele hacer en los sistemas escolares, donde los contenidos están establecidos por la hegemonía de un sentido común y unos intereses mercantiles. Un sentido común que procede del sentido práctico que no cuestiona los sucesos históricos, que se creen que proceden de fuerzas naturales, y de unos intereses 
mercantiles de empresas editoras de manuales escolares y academias que venden productos culturales de consumo inmediato.

Si no lo hacemos así, si no cuestionamos la cultura que enseñamos en nuestras aulas, "GCE can be seen as harbouring competing and contradictory discourses critical democracy and neoliberalism", como afirma W. Ross. Por eso entiendo que la primera labor que se debe hacer en la enseñanza es un estudio de los contenidos que desarrollamos escolarmente (hechos conceptuales, procedimientos de aprendizaje y explicaciones realizadas) y ver cómo puede participar de forma crítica el alumnado (que son ciudadanos/as) en su elaboración. Algo que venimos defendiendo desde hace más de treinta años.

ROSS: I agree that the pandemic and its effects are best understood as simultaneously a global and local event. Even in epidemiological terms the pandemic is actually a collective of pandemics that are playing in different ways in different localities. And our current situation provides an opportunity to engage people in understanding and analysis of global/local ("glocal") interconnections in social, political, economic, and environmental terms.

I agree with Professor Souto that we should be "impugnando las representaciones sociales del saber escolar, que simplemente es un compendio de hechos asentados en la cultura capitalista occidental y una forma de razonar propia del liberalismo individualista". In my view this an imperative for social studies educators. For example, capitalism demands constant growth. As David Harvey has said a slowdown or blockage in the flow of capital will produce a crisis, when the capital flow stops the "body politic of capitalist societies dies". The pandemic has created economic crisis and that is why in many instances we have seen politicians focused on quickly "reopening the economy" - valuing the economy and profits over the interests and health of the vast majority of people. More than one politician has voiced the idea that people, particularly seniors, should be willing to die from coronavirus to maintain the economy. How can anyone make meaning of such callous views with understanding them within the system of global capitalism and what it demands of us? Global capitalism created the conditions for the spread of coronavirus as well as creating healthcare systems and political cultures that are not willing or able to respond the threats that result, creating a vicious cycle. And, of course, there is a direct relationship between capitalism and planetary destruction via climate change. As the slogan goes, "we need system change to defeat climate change". 
Pedagogically speaking, we typically approach teaching about any global issue by starting with some element or small part and establish connections to other elements in an effort to eventually construct the complete picture. Instead, I think we would create more powerful opportunities for students to create meaningful understandings of the work if we began by examining the whole, the system (or as much of it as we can understand) and then examine the parts to see how they fit and function. Whether we're making sense of the pandemic, economic crises, or the role and aims of global citizenship education.

SOUTO: La clave, desde mi punto de vista, reside en la relación sujeto y contexto social. Y además en la representación que tienen de este marco que delimita sus actuaciones y responsabilidades. Es un ámbito de investigación que ya tiene su repercusión en la enseñanza, además del propio campo disciplinar de los problemas sociales.

Las personas que conocemos en la categoría de alumnado tienen sus justificaciones personales en las condiciones de vida de sus familias, amigos, barrio, medios materiales de subsistencia... pero en el momento en que ingresan en un centro escolar son ALUMNOS. Es decir, la sociedad tiene una manera de homogeneizar comportamientos que acaban generando comportamientos exculpatorios o de responsabilidades sistémicas; a veces, generan una imagen de auto-culpabilización. En la pandemia lo vemos con claridad en las acusaciones o absoluciones de culpa para algunas personas que no llevan máscara, que no respetan las distancias... Se busca justificar desde un comportamiento individual todo un sistema social y político.

Para poder abordar la explicación del todo creo que se debe proceder desde los supuestos de casos individuales tópicos. Habrá que saber identificar cuatro/cinco casos de comportamientos esperados y observados que nos permitan debatir los factores que condicionan determinado "sentido práctico" del actuar y decidir. Una vez que se analicen los factores los podremos relacionar en una teoría explicativa. Pero, como digo, es preciso observar y ver cómo observan las personas. En este sentido, la Geografía de la Percepción y del Comportamiento nos ayuda a relacionar las imágenes del espacio personal que construimos en el cerebro. Son imágenes que van asociadas a valores y actuaciones sobre el medio, con lo que ello implica para la conservación o destrucción del mismo.

Respecto a lo que señala el profesor Ross en relación con la falsa dicotomía salud/economía estoy completamente de acuerdo. Es una aberración que se plantee esta disyuntiva, lo cual también ha sucedido en España, pues un razonamiento lógico nos dice que la economía solo puede funcionar si hay personas que producen 
y consumen. Lo que nos hace sospechar que las personas que emiten estos juicios están especulando con el número mínimo de personas necesarias para que funcione el engranaje capitalista. Es decir, buscan un umbral de demanda que asegure la reproducción de las ganancias para ciertas empresas e individuos. Esta disyuntiva tiene una repercusión educativa muy relevante, pues se puede plantear el problema de la muerte en la sociedad actual y los procesos históricos que la han determinado (eutanasia, genocidio, holocausto...). En este sentido creo que lo más oportuno es relacionar el ámbito particular, individual, con el contexto global, teórico y más abstracto. Es preciso otorgar el valor de praxis al conocimiento escolar sobre los problemas sociales. Y ello se puede hacer relacionando las anécdotas individuales con las explicaciones teóricas. Y sobre todo poniendo de relieve las contradicciones entre las declaraciones al valor supremo del individualismo y la búsqueda de la protección del Estado para negocios particulares.

La Geografía con el análisis de los global y local con la metodología de la superposición de escalas tiene un conjunto de instrumentos técnicos (cartográficos, estadísticos, icónicos, verbales) que permiten comunicar con otras personas y plantear problemas locales desde una posición universal. Sobre todo, permite explicar cómo se generan sentimientos y emociones respecto a un espacio geográfico desde instituciones políticas, medios de comunicación y empresas. Estas van generando lo que se considera un sentido práctico de actuar, que se quiere conceptualizar como sentido común.

INTERVIEWER: In this context, how should Critical Literacy be implemented in education? Should it appear in the educational law? When should we start to teach it? How should we approach it?

ROSS: These are good questions, and I will try to follow up directly from my prior response regarding GCE. Working from the notion that neoliberalism and education are incompatible, we have to consider critical literacy not as a method to be accommodated into our current ideas of what constitutes schooling, teaching, or learning. It certainly cannot be mandated, at least not without stripping it of its essence. Simply put, critical literacy is about a process of coming to understand that things are not as self-evident as one believed. You could say the same about critical pedagogy or critique, indeed this is Foucault's description of what critique is. Critical literacy is a process of reading the word and the world and identifying and challenging familiar, unchallenged or unconsidered assumptions underlying our thought, logics, and practices and trying to change things. Critical literacy is not a method, it is a way of being in the world. For Paulo Freire, critical literacy is 
grounded in dialogue and aimed at liberation from oppression. A Freirean response to this particular question is that all critical literacy practices should involve analysis, reflection, and dialogue about social and political life. And dialogue is the center of the process; not just dialogue with a text but being in dialogue and communicating with others. The aim of literacy in Freirean terms is for students to understand that language is not objective but is created by humans for human purposes. That is, for students to come to understand they have the power and responsibility to create meaning. This reflects what has been called an activist conception of human beings and implies that people create themselves on the basis of their own self-interpretation, but under already existing circumstances given and transmitted from the past. This conception of can be understood as a function several dispositions: intelligence (the ability to alter one's beliefs and actions based on new information), curiosity (that which compels us to see new information for making judgements), reflection (evaluating our desires, beliefs, and actions), and willfulness (acting on one's reflections).

Friere and John Dewey share a number of similarities in their philosophies of education, most importantly the idea that education is not about preparation for life, but life itself. An educative experience suggests the past is part of who we are now and that the present is important as the preconditions for resolving major social contradictions in the future. These kinds of experiences help us construct personally meaningful understandings of the world and in the process to make change. This is a description of Dewey's experiential approach to education and applies equally well to Freirean literacy. As I social studies educator, I emphasize investigating social issues (an example of what critical literacy looks like) because social issues provide an opportunity for examining the history of an issue, its social context now, and to think about what the issue means for us in the future. Studying how people (and things) change is the heart of social understanding. For me, perhaps the most compelling element of social issues education is that active investigation of social issues contributes to change.

SOUTO: Mi propuesta consiste en analizar los comportamientos ciudadanos para poder decidir el futuro que deseamos construir. Y ello pasa por: a)analizar los valores y deseos que manifestamos sobre nuestra vida en comunidad (en especial en una escala histórica concreta y en un marco espacial local); b)explicar los prejuicios culturales que se difunden sobre la diversidad de concepciones que existen sobre las relaciones interpersonales y la manera de organizar el tiempo y el espacio colectivo; c)argumentar sobre las consecuencias políticas para la participación ciudadana que se derivan de los marcos institucionales que regulan nuestra 
vida personal y social. Para poder desarrollar estos principios de explicación social es preciso seleccionar algunos pocos problemas sociales significativos y desarrollar secuencias de aprendizaje con recursos materiales (textos, gráficas, imágenes...) que se puedan construir en la comunidad escolar y no importarlos de empresas que tienen sus propios intereses en construir un discurso aparentemente ciudadano y democrático, pero que limita la capacidad de participación de las personas en sociedad.

Hay una coincidencia con lo que se expresa por W. Ross "This conception of can be understood as a function several dispositions: intelligence (the ability to alter one's beliefs and actions based on new information), curiosity (that which compels us to see new information for making judgements), reflection (evaluating our desires, beliefs, and actions), and willfulness (acting on one's reflections)". Mis matices van en el camino de utilizar la inteligencia para impugnar las 'verdades' del sentido práctico, ese que nos obliga a hacer lo que no deseamos. La curiosidad se desarrolla en relación con proyectos, como ha sido el caso del proyecto Gea-Clío, que ha pensado un proyecto curricular en 1989/90 para desarrollar posteriormente (hasta la actualidad) y eso nos hace ser curiosos, impertinentes, cuestionando la información que llega sobre 'novedades' que no son tales en el ámbito de las Nuevas Tecnologías y la metodología didáctica. Reflexión, sin matices; aquí hay una coincidencia básica en valorar nuestros deseos a la luz del comportamiento esperado. Y finalmente obstinación, que para nosotros es la praxis, la lectura de la práctica desde los anteojos de las teorías interpretativas de los hechos sociales. Y en este ámbito de la reflexión teórica es donde aparecen las escalas temporales y espaciales. No es lo mismo analizar un fenómeno en un tiempo corto, en una coyuntura determinada, que desde la perspectiva del tiempo largo, de las estructuras. Los tiempos de Braudel son una ayuda esencial. Como lo son las Unidades de Magnitud de Lacoste, que nos permite reflexionar sobre los tamaños de las unidades políticas que se utilizan vulgarmente por los medios de comunicación.

ROSS: We share very similar ideas pedagogy and curriculum of critical literacy. As Professor Souto points out when the curriculum and topics of study are connected to issues of importance to the community and/or the interests and curiosity of students the aims, processes, and outcomes of social studies education are dramatically different from corporate-based curriculum that is standardized and based on the interests and aims of governments and the ruling class.

The history of social studies education in North American provides myriad examples of curriculum that are built upon inquiry into society and self and that 
incorporate analysis of personal values, examination of cultural prejudices, debating the process and outcomes of social policies. For example, The New Social Studies projects of the 1960s and 1970s - The Public Issues Series, which was part of the Harvard Social Studies Project, and Man: A Course of Study, as well as the High School Geography project and others - were curriculum projects that prioritized inquiry-based learning, discussion and decision-making. Unfortunately, these projects and the priority of inquiry learning were abandoned by schools long ago, primarily as a result of the rise of cultural conservativism coupled with an education reform movement that emphasized bureaucratic outcomes-based accountability in which students, teachers, and school administrators were held accountable to government agencies for demonstration academic success based upon a small set of indicators of individual student performance (test scores). Education reform that disrupts or makes impossible the critical curriculum and learning experiences we are talking about here flows from neoliberal capitalist worldview which reduces education to a commodity and demands that schools focus on workforce preparation to the exclusion of personal learning and development, student agency and connection of school learning to everyday life circumstances that are most important to students.

SOUTO: Me reconozco en las palabras de W. Ross, que sin duda siguen la senda marcada por Dewey y Freire, cuando consideran que "critical literacy is not a method, it is a way of being in the world". En efecto, muchos debates en la educación proceden de la cosmovisión que tienen los sujetos y que, más de una vez, no se suele explicitar. Pero un docente crítico e innovador en su praxis no puede quedarse en el mundo de las concepciones y juicios personales. Es preciso contrastar púbicamente sus pensamientos. Y es, entonces, cuando entra en liza la metodología.

Mi experiencia de muchos años trabajando en la formación continua e inicial me indica que existe una confusión entre metodología y métodos, que en gran medida está condicionada por las modas y por las lecturas apresuradas de la filosofía de la ciencia. La metodología en educación debe guiarnos a unos fines, que están condicionados claro está por la cosmovisión, que se debe hacer explícita. Pero además por los procedimientos que utilizamos para afirmar que estamos produciendo conocimiento, que facilitamos el aprendizaje de otras personas. $\mathrm{Y}$ en este sentido, la metodología implica definir bien el problema (sin dispersarse) y buscar unas técnicas de trabajo que permitan verificar las hipótesis que se han planteado para solventar los problemas enunciados. Técnicas que se pueden englobar en métodos cualitativos y cuantitativos. 
Las modas y costumbres de los dos primeros decenios del siglo XXI han querido utilizar la sinécdoque de una parte (método) por el todo (la metodología). Y ello apoyado en el recurso retórico de la objetividad de los datos numéricos. La pandemia ha revelado la falsedad de esta afirmación. Los datos 'hablan' cuando les sabemos preguntar. Cuando sabemos formular las preguntas adecuadas, así han sido frecuentes las técnicas que han utilizado datos absolutos cuando debían ser relativos, o a la inversa; por ejemplo, en un lugar concreto interesa tanto el valor relativo del contagio como, sobre todo, la saturación del número absoluto de camas hospitalarias, sobre todo UCI. E igual cuando se comparan datos para obtener tasas, como ha sido el equívoco entre tasas de mortalidad y letalidad. Pero, sobre todo, lo que más nos preocupa es la falta de análisis cualitativo; es decir, a quiénes afecta estos números: no es lo mismo una ocupación de una UCI en España que en Perú, por poner un ejemplo de recursos quirúrgicos, no es igual la atención primaria que pueden recibir las personas blancas y con seguro médico en Estados Unidos que aquellas (sobre todo afrodescendientes) que no tienen seguro médico. Todas estas cuestiones se pueden plantear en clases con adolescentes y jóvenes, para educarlos de forma crítica ante el mundo en el que viven, donde la saturación informativa no les permite identificar problemas y las rutinas del tiempo presente les impiden ver la trayectoria del conocimiento científico.

INTERVIEWER: The first news of the epidemic came from China. In other parts of the world, Chinese descendant people were pointed out. People started not to go to their restaurants, bars, groceries etc. Donald Trump, with his particular rhetoric, called Covid-19 'the Chinese virus'. Later on, it became clear that the virus was a global issue, however some peoples' first reaction was to put the blame on China and worlds' Chinese communities.

There is little research on Hate Speech and the construction Counter-Hate Speech narratives in educational and curricular studies. What should be the path of this research line in the future? Considering there are lots of spaces of socialization apart from school, do you think formal education could make the difference on stopping hate speech and building counter-hate speech narratives?

ROSS: Hate speech poses extraordinary challenges in the current moment. It has been particularly exacerbated by authoritarian nationalist leaders such as Trump and others who have normalized racist, misogynist, anti-LGBTQ, views as part of the everyday political discourse. This is an area where we already know what should be done, so I'm not convinced that we need new lines of research so much as we need to look to construct educational experiences that foster humane 
and progressive social values. There have been many thousands of studies of ways to counter racism, sexism, ableism, Islamophobia, etc. What is needed is the will to enact educational practices that like those I was just describing. Critical literacy, critical pedagogy, and critical democratic education are all part of the solution. We already have access to extraordinarily useful curricular materials to combat many of these issues in the classroom. The New Social Studies curricula of the 1960s and 1970s comes to mind as well as curriculum materials focused on helping students understand and embrace more progressive and accepting dispositions regarding cultural differences, sexual orientation and gender identity, etc.

Schools certainly have a responsibility for actively countering hate-speech, but it's important to not hold schools harmless for having a more positive impact on their graduates social and political views. Deploying edicts against hate-speech has little to no impact in suppressing the expression of such views. Schools and communities need to have the political will to engage in critical examination of the origins and nature views that propagate hate. Worthwhile curriculum knowledge takes the form of personal meanings that express both truth and value (intelligence and a moral stance).

SOUTO: Quiero partir de la frase anterior del profesor Ross: "Critical literacy, critical pedagogy, and critical democratic education are all part of the solution. We already have access to extraordinarily useful curricular materials to combat many of these issues in the classroom". Mi punto de vista es algo diferente. Tal como señalaba en la cuestión anterior es preciso abordar los problemas sociales desentrañando las escalas temporales y espaciales, que nos ponen sobre la superficie una serie de factores ocultos que se esconden en la vorágine de los hechos contados en los diferentes mecanismos que tiene internet para crear una dispersión de nuestra atención: Facebook, Instagram, Twitter... Al analizar los discursos que se transmiten en las redes podremos explicar cómo se difunden los relatos sobre 'los otros', además, así, en masculino. Coincido con Ross respecto a la inutilidad de crear más teorías. Quizá los nombres nos pueden dar lugar a más dispersión. La literacidad crítica, la pedagogía crítica y la educación democrática crítica son conceptos que deben ser entendidos en su marco histórico. Por eso, cuando alude a los Nuevos Estudios Sociales de los años sesenta y setenta del siglo pasado, a mí me ha venido a la cabeza los Curriculum Project de la educación geográfica en el Reino Unido, en lo que los británicos denominaron Golden Age. Y eso porque fue un momento en que existía una confianza en el profesorado, que se organizaba en los Centros de Profesores de forma autónoma y creaba materiales en relación con problemas sociales. 
Para combatir el odio es preciso analizar las causas de este, pero hay que hacerlo con proyectos donde niñas y adolescentes puedan implicarse en el estudio de su realidad próxima (cerca o lejos físicamente, que es otra cuestión). El odio puede surgir como un intento de legitimar una determinada identidad para proteger los derechos de un grupo. Habrá que examinar qué intereses, qué grupos, qué enemigos se creaban en el interior de la comunidad y cuál era el exterior, que pretendía desarrollar así una política de nacionalismo hostil al diferente. Y lo mismo sucede respecto a la política de género, que además es más fácil de llevar adelante si confiamos en que nuestros chicos y chicas puedan aportar sus deseos y expectativas respecto a la convivencia en grupo, donde las diferencias son un valor. Pero para ello es preciso que los docentes no practiquen la segregación en sus clases, clasificando a los alumnos/as en listos, burros, obedientes, rebeldes e indisciplinados. Hay problemas que se podrían evitar si en las clases y centros escolares practicáramos una forma de actuar más plural y menos segregadora. Pero para ello los/las docentes tienen que ejercer la praxis y pensar en las dificultades y posibilidades de ejercer el desarrollo de la autonomía personal de sus alumnos desde una concepción de la clase que es común para un determinado canon del saber.

ROSS: Do I think official curriculum endeavors could make a difference in reducing hate speech and building hate-speech counternarratives? Yes, I think it can and, in some instances, does. But it is important to remember that schools themselves cannot be held harmless for the perpetuation of prejudices such as racism, sexism, ableism, Islamophobia and heterosexism. Official school curriculum is responsible for perpetuation of social and cultural prejudices as well as economic inequalities whether it be in regard to Indigenous peoples, religion, race, ability, sexual orientation, etc. Schools are sites of an unresolved ambiguity, the source of both alienation and-at least potentially-emancipation. Are schools the source of hidden riches and starting points for the construction of counternarratives to hate speech or even transformation of society or are they impoverished zones that perpetuate prejudice and hate, at least some of the time? This remains an open question, but just barely. Generally speaking, schools reflect the societies in which they exist, for good and ill. This is why educational practices that call into question the mainstream views or practices of society rarely get a foothold in the classroom. This is why critical curriculum and pedagogical programs, for the most part, are like unicorns, even if they do exist, they are quite rare.

I believe that authentic education is a process of constructing a critical knowledge of everyday life, so of course countering hate speech in schools starts with students, teachers and other school workers experiences. Formal curriculum 
that aims impose a 'liberal' or 'accepting' social perspective on students are not likely to produce the desired result. What is necessary in constructing counternarratives to hate speech is environment that fosters dialogue and that is willing to tolerate disagreement, while also providing safe spaces. Countering hate speech requires that students have the opportunity to engage in serious dialogue on issues that maybe quite sensitive or threatening and it requires teachers who are able to create classroom conditions that foster some measure of trust and openness to a wide range of ideas. These are the conditions necessary for democratic dialogue, something else that is rare in schools and society. If there is significant commitment on the part of education, social, and political leaders to countering hate speech; if teachers are willing to prioritize it in their classrooms; and if there is some measure of support withing schools and society for the effort then, yes, there is possibility for schools to have a positive impact on speech practices.

We can see an example of this in the social studies curriculum in British Columbia where social justice issues and in particular a focus on sexual orientation and gender identity have be prioritized in recent years. But even in this province, which has a reputation for being culturally liberal, there are school districts that refuse to offer the social justice course and, of course, not everyone is supportive of this or other efforts to create a more open and accepting society for a variety of reasons ... the sources of hate as Prof. Souto mentioned need to be analyzed, but analysis alone is not enough.

SOUTO: Me parecen muy adecuadas las precisiones del profesor Ross: "Official school curriculum is responsible for perpetuation of social and cultural prejudices" y "the sources of hate as Prof. Souto mentioned need to be analyzed, but analysis alone is not enough". En primer lugar, los planes de estudio. Aunque voy a describir una verdad obvia (la diferencia entre el curriculum oficial y el real) creo que es importante partir de este hecho. El currículo llega a las aulas después de ser legislado por unos representantes del poder político ciudadano. Las instituciones educativas (Inspección, asesores de formación continua, profesores de formación inicial de las universidades) y empresariales (empresas editoras de manuales escolares, de páginas web educativas) interpretan el currículo según sus necesidades y satisfacción. El profesorado tiene poco tiempo para ejercer una lectura crítica de dichas programaciones, por eso las rutinas se perpetúan. A mi modo de ver tiene toda la razón W. Ross cuando indica que no nos podemos quedar en el análisis de los problemas (el análisis por sí solo no es suficiente). Por eso estamos impulsando, en compañía de otros colegas iberoamericanos, el programa ¡Nós Propomos!, que se inicia con el activismo de Sérgio Claudino en el IGOT de Lisboa y se difunde en 
España gracias a las Universidades de Castilla-La Mancha y Valencia. Se basa en una metodología sencilla: analizar los problemas locales básicos y proponer una solución a las autoridades locales. Los diálogos, con sus encuentros y desencuentros, con los responsables de la gestión municipal es toda una escuela de participación ciudadana. Así tenemos a miles de personas que están participando en este proyecto colectivo, que se relaciona directamente con el Geoforo Iberoamericano de Educación, pues en sus foros son los/las alumnas universitarias y sus profesoras quienes se esfuerzan por buscar conceptos y teorías que desde el contexto global puedan explicar los factores que determinan los problemas y, por eso mismo, facilitan la construcción de soluciones.

INTERVIEWER: The world in general and society in particular are changing all the time. Nowadays, it seems that they are moving and changing faster than ever. This pandemic has changed the world as we know it, but there's no need for a pandemic to change the world since every new technology, conflict, injustice... that comes up around the world affects our lives in one way or another.

How should education face the challenge to adapt this everchanging times? What should social studies education be like nowadays and in the future? How could we teach students that they can write their own future?

ROSS: As I mentioned earlier, I believe that neoliberalism and education are incompatible. It matters what we mean when using the term education. Too often we conflate education and schooling, and this is part of the problem. Of course, the giving and receiving of systematic instruction in schools, and elsewhere, is a key means by which the politics of truth are officially defined. Public schools, that is government sponsored schools, have been and continue to be profoundly conversing in nature, illusion factories whose primary aim is reproduction of the existing social order, where ruling ideas exist to be memorized, regurgitated, internalized and lived by. The conditions of neoliberal capitalism have led to a widespread decline of authentic educative experiences to the point that the recent history of education (or at least schooling) can now be understood as the decline from being into having, and having to into merely appearing to have an education.

The Global Education Reform Movement (GERM) is a name for the organized as form of neoliberal education, which includes: increased competition between students and schools; commodification of education via 'school choice', which positions students and parents as consumers in an education marketplace; and powerful systems of accountability tied to standardized testing and the standardization of what can be taught and learned in schools. This corporate/state 
regulation and administration of knowledge, is a move that enables "systems of unaccountable power" (Chomsky's phrase) to make self-interested decisions ostensibly on behalf of the public when, in fact, most members of the public have no meaningful say in what or how decisions are made or in what can count as legitimate knowledge. This, of course, is purposeful and involves the coordinated control of such pedagogical processes as goal setting, curriculum development, testing, and teacher education and evaluation, the management of which works to restrict not only what and who can claim the status of 'real' knowledge, but also who ultimately has access to it. GERM marketizes (or 'deregulates') public education systems, opening the door for extraction of profits from a public service via school management (education management organizations); off-shore schools and selling seats in schools and universities on the international market; massive regimes of standardized testing that are boon to publishers selling the tests and the textbooks; using public money to support private schools via vouchers, etc.

While public education is forced into the economic marketplace, the marketplace of ideas is shut down. What exists here is an unambiguous, power-laden connection between the regulation of knowledge on the one hand and the (de)regulation of the economy on the other, a joint effort by the politically, culturally, and economically powerful (nominally on behalf of the public) designed to stifle popular democracy while simultaneously enhancing the profits of multinational corporations and the ultra-rich. It is a reproductive and circular system, a powerknowledge-economics regime in which the financial gains of a few are reinforced by what can count as school (and thus social) knowledge, and in which what can count as knowledge is determined so as to feed the financial greed of corporations. This is the process of schooling. A process that little to do with education and which I hope sheds a little more light on my claim that neoliberalism and education are incompatible.

My hope, of course, is that we can reverse the deleterious effects of neoliberal schooling on what counts as education. That is, education should not be seen as collection of credentials to be cashed in for future economic rewards. My hope would be that we might find ways to create access to education as a process of becoming - a transformational process that fundamentally alters our understanding of self, others, the world, and our relationship with the environment. This would be an education that is social process that leads to individual and social change - not a commodity that can be bought or sold. 
Earlier I said that worthwhile knowledge takes the form of personal meaning that express truth and value. I believe that reduced to its most basic elements, schools should seek to create conditions in which students can develop personally meaningful understandings of the world and recognize they have agency to act on the world, to make change. Education is not about showing life to people but bringing them to life. The aim is not getting students to listen to convincing lectures by experts but getting them to speak for themselves in order to achieve, or at least strive toward an equal degree of participation and better future.

SOUTO: Empiezo también con otra frase del profesor Ross. "This corporate/state regulation and administration of knowledge, is a move that enables "systems of unaccountable power" (Chomsky's phrase) to make self-interested decisions ostensibly on behalf of the public when, in fact, most members of the public have no meaningful say in what or how decisions are made or in what can count as legitimate knowledge". Creo que es preciso definir qué entendemos por escuela pública y cómo se define lo público en la educación. Yo entiendo lo público como un proceso, como una aspiración utópica, esa meta que se mueve para que sigamos avanzando en una determinada dirección. Una escuela de un empresario o de una cooperativa es una escuela que se refugia en el ámbito de propiedad privada para construir, o no, un modelo de educación público. Pero eso supondría renunciar a sus privilegios de propietarios de un solar y de un 'ideario' de centro escolar. Y el análisis empírico nos muestra que eso no ha sido así. Se pueden encontrar algunos avances en la participación de familias y alumnos/as en la gestión educativa escolar, pero no es el ámbito de lo público, pues a veces los individuos están restringidos en su participación por sus capacidades económicas. Tampoco es público un centro escolar que siendo propiedad el edificio del Estado y siendo pagados los salarios por el Estado, se practica una enseñanza al margen de las preocupaciones de la comunidad escolar: alumnado, familias, vecinos e instituciones representativas. Generalmente los profesores/as han patrimonializado el concepto de lo público, no lo han reflexionado en la praxis educativa.

Por tanto, podemos deducir que lo público es una cualidad de proceso, como la verdad en filosofía, que tiene condiciones necesarias, pero insuficientes. En primer lugar, para aspirar a un centro de educación pública es preciso que cualquier persona pueda acceder, más allá de su ideología y capacidades económicas. Lo que no siempre es así, por lo menos en España en centros privados y muchos concertados. Coincido así con la frase de Ross: "schools should seek to create conditions in which students can develop personally meaningful understandings of the world and recognize they have agency to act on the world, to make change”. Yo añadiría que 
pueden actuar en el mundo en las diferentes escalas en que este se presenta. Por eso, en segundo lugar, pensando cómo se podría mejorar la convivencia en los centros escolares, debemos desarrollar pautas de participación social en la gestión del mismo: proyectos con la comunidad, actividades de aprendizaje en servicio, por ejemplo.

Si la finalidad primera de la educación es desarrollar la personalidad integral del ser humano, será preciso debatir en comunidad cuáles son los aspectos de la personalidad que conviene potenciar en un momento determinado para la socialización colectiva y la felicidad individual. Eso supone analizar los tiempos y espacios de la socialización de los individuos y su comportamiento respecto a sus deseos y expectativas. Aquí es donde aparece el valor de la educación y más concretamente de quienes nos dedicamos a las ciencias sociales, entendidas como formas conocimiento que hacen posible la elucidación de los problemas y dilemas que nos preocupan.

ROSS: Curriculum and teaching are contested terrains because deciding what ought to be case be it about curriculum or teaching and learning practices, is a normative issue. I advocate an approach that takes seriously the personal development of individual students while also emphasizing the importance of informed social criticism for understanding society and cultivating a sense of personal agency. Paulo Freire, in speaking of citizenship and freedom, said that they are not obtained by chance, they are constructions that is never finished and demand that we fight for it. That fight demands that we have a commitment, political clarity, and coherence. I would say the same about education, and social studies education in particular.

SOUTO: El proceso de disputa del curriculum y la enseñanza es un debate político, donde debemos participar. En educación existen algunos conceptos que son invenciones académicas para describir las acciones que ejecutan los sujetos. El problema de algunos vocablos es que se banalizan por su uso frecuente sin reflexionar en su implicación en las acciones de los sujetos. Es el caso de currículo, que para algunos profesores es un conjunto de elementos (objetivos, contenidos, competencias, criterios de evaluación, estándares de aprendizaje) que se deben cumplir y generan una acción burocrática que implica mucho gasto de energía sin saber las repercusiones en la mejora del aprendizaje del alumnado. Se realizan estas tareas sin saber los motivos para los cuales se solicita su ejecución y ello provoca frustración y genera desconfianza en la comunicación educativa. Por eso a las peguntas ¿Cómo debería ser la educación en estudios sociales hoy y en el futuro? ¿Cómo 
podríamos enseñar a los estudiantes que pueden escribir su propio futuro?, nosotros contestamos desde la concepción de un proyecto curricular que elaboramos de forma colectiva día a día, mes a mes, año tras año. Se conoce como proyecto GeaClio; es decir define dos coordenadas que sirven para explicar los problemas sociales: la dimensión temporal y la espacial.

Nosotros queremos acompañar el aprendizaje del futuro deseado por los/las jóvenes desde el estudio de los factores que están ocultos bajo la apariencia y superficie de las noticias que aparecen en los medios de comunicación y en las plataformas de las redes sociales. La saturación informativa que condiciona la visión y comprensión de la realidad debe ser impugnada con conceptos rigurosos y relevantes para entender el mundo en que vivimos. Hemos apostado por organizar el currículo del sistema escolar con pocos problemas (no más de cuatro o cinco cada año escolar) para poder abordarlos con un tiempo lento, que permita reflexionar sobre los elementos y factores que se ocultan en la mercantilización de la información, que se ha convertido en un espectáculo. Explicar actualmente los problemas sociales es muy complejo. Se necesita primero desenmascarar lo que no nos deja apreciar la realidad desde nuestros sentimientos más profundos, que se han pervertido por la influencia del bombardeo mediático. Por eso coincido con W. Ross en defender una educación que enfatice la importancia de la crítica social informada. Pero esto requiere tiempo. Algo que no se puede hacer cuando un currículo se transforma en un listado de temas que genera una ansiedad por cumplir un programa escolar.

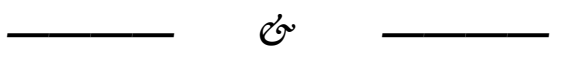

\section{JORDI CASTELLVÍ MATA}

Jordi Castellví has a degree in History and Primary Education, and a PhD. in Education (2019). His interests are research methodologies, global citizenship education, the phenomenon of populism and the development of critical thinking in digital contexts. Castellví had a scholarship from the Spanish Ministry of Economy and Competitiveness as part of the R\&D EDU2016-80145-P project at the Universitat Autònoma de Barcelona, where he has worked as a research fellow of Social Studies Education. He is currently a lecturer at the UNIR (Universidad Internacional de la Rioja).

jordi.castellvimata@unir.net https://orcid.org/0000-0002-6487-5477

Castellví Mata, J. (2021). Read the world to write the future: An interview with professors E Wayne Ross and Xosé Manuel Souto, experts in critical social studies. Bellaterra Journal of Teaching \& Learning Language \& Literature, 14(2), e974. https://doi.org/10.5565/rev/jtl3.974 